Short Communication

\title{
A preliminary investigation on emission of polychlorinated dibenzo-p-dioxins/dibenzofurans and dioxin-like polychlorinated biphenyls from coke plants in China
}

\author{
Guorui Liu, Minghui Zheng*, Te Ba, Wenbin Liu, Li Guo \\ State Key Laboratory of Environmental Chemistry and Ecotoxicology, Research Center for Eco-Environmental Sciences, Chinese Academy of Sciences, \\ P.O. Box 2871, Beijing 100085, China
}

\section{A R T I C L E I N F O}

\section{Article history:}

Received 22 October 2008

Received in revised form 6 January 2009

Accepted 7 January 2009

Available online 11 February 2009

\section{Keywords:}

Dl-PCBs

PCDD/Fs

Coking

Emission

Inventory

\begin{abstract}
A B S T R A C T
Thermal related processes are widely recognized as the main sources of formation and emission of polychlorinated dibenzo-p-dioxins/dibenzofurans (PCDD/Fs) and polychlorinated biphenyls (PCBs). It is well known that, carbonization of coal in coke production involves many thermal reactions at high-temperature. However, there are still no strong evidences to identify coking processes as source of PCDD/Fs and PCBs. In this study, coke production was qualified and quantified for emission of PCDD/Fs and dioxin-like PCBs (dl-PCBs) in some typical coke plants in China. In the preliminary investigation, stack gases from three typical coke plants were collected, and dl-PCBs and 2378-substituted PCDD/Fs were analyzed by isotope dilution HRGC/HRMS technique. The total toxic equivalents of dl-PCBs and PCDD/Fs were in the range of $1.6-1785.4 \mathrm{pg}$ WHO-TEQ Nm${ }^{-3}$. For dl-PCBs, the most abundant congener was CB-118, and the most dominant contributor to total WHO-TEQ of dl-PCBs was CB-126. With regard to PCDD/Fs, four congeners comprised of OCDD, 1234678-HpCDD, 1234678-HpCDF and OCDF were the predominant species in stack gases. Further investigation on the emission of dioxins from coking industry is still in process.
\end{abstract}

(c) 2009 Elsevier Ltd. All rights reserved.

\section{Introduction}

Polychlorinated dibenzo-p-dioxins/furans (PCDD/Fs) and dioxin-like polychlorinated biphenyls (dl-PCBs), often termed as "dioxins", are notorious persistent organic pollutions (POPs). Once released into the environment, they can be dispersed on global scale and poses serious health and environmental risks. In order to control and reduce further environmental exposure of POPs (including dioxins) on a regional and global scale, Stockholm Convention on POPs was adopted in May 2001, and came into force on May 17th, 2004. The source identification and characterization of dioxins emission is the key step for the implementation of Stockholm Convention. The dioxins emission sources comprised of waste incineration, ferrous and non-ferrous metal production, heat and power generation, and so on (UNEP Chemicals, 2005). Many investigations have been conducted on various anthropogenic combustion and thermal related sources, which are widely recognized as the most major pathway of dioxins formation and emission. For some potential sources, there are still considerable uncertainties about the fluxes of dioxins into the environment. Coke production is considered as one of potential dioxins sources

\footnotetext{
* Corresponding author. Tel.: +86 10 62849172; fax: +86 1062923563.

E-mail address: zhengmh@rcees.ac.cn (M. Zheng).
}

where the formation and emission of dioxins might occur during charging and heating of the coal, and discharging of the coke. However, the available data on release of dioxins to the environment is very scarce. To our knowledge, only one case study by Bremmer et al. (1994) reported the monitoring of PCDD/Fs emission from a coke plant with an annual production capacity of 670 thousand tonnes. The emission concentration in the exit gases was $0.15 \mathrm{ng}$ I-TEQ $\mathrm{Nm}^{-3}$. An emission factor of $0.3 \mu \mathrm{g}$ I-TEQ tonne ${ }^{-1}$ was de-

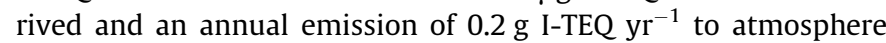
from the coke plant was estimated.

Compared with PCDD/Fs, investigations on dl-PCBs emission from stationary sources are rare, existing researches about dl-PCBs emission mainly focused on incinerators (Pernin et al., 1998; Dyke et al., 2003) and iron ore sintering plants (Aries et al., 2006). No study on dl-PCBs emission from coke plants has been reported up to date.

The global output of coke was about 558 million tonnes in 2007, and the activity rate of coke production was thus tremendous. China is the largest coke producing country in the world, many coke plants with different scales and techniques being in operation. The annual output of coke reached up to about 335 million tonnes in 2007, which took up about $60 \%$ of global coke production. The development of dioxins inventory from coke plants in China is significant for evaluating dioxins release in coking industry in the world. 
The formation and emission of dioxins might occur during the charging of coal, heating, and ejection of coke. Since the heating temperature in coke ovens is higher than $1000^{\circ} \mathrm{C}$, the formation of dioxins might be ignored. Therefore, the release of dioxins might mainly arise from the charging of coal and ejection of coke. Although there exist the hundreds of coke plants in China, few plants are suitable for field sampling. In order to learn about the dioxins emission levels during charging of coal and ejection of coke, three typical coke plants (CP1, CP2 and CP3) were selected in this preliminary study. The mixed emission gas during the charging of coal and ejection of coke was collected for CP1. The released gases during the ejection of coke and the charging of coal were collected for $\mathrm{CP} 2$ and $\mathrm{CP} 3$, respectively. The concentrations of dl-PCBs and 2378-substituted PCDD/Fs in stack gases were analyzed by isotope dilution HRGC/HRMS technique. The emission levels and congener profiles of dl-PCBs and PCDD/Fs in the stack gases from the three plants were presented and discussed.

\section{Materials and methods}

\subsection{Sampling}

Three coke plants with different scales and techniques were selected and the related information was described in Table 1. Coke was produced by carbonization of coal in the absence of air at approximately $1000{ }^{\circ} \mathrm{C}$ in coke ovens, and then coke was removed and quenched with water or dry inert gas. The end-of-pipe control of three coke plants were described as follows. The emitted gases from charging of coal and the pushing of coke were treated by two separate dust arrestors (bag filters, BF) for both CP2 and CP3. For $\mathrm{CP} 1$, only one dust arrestor (BF) was used for the treatment of exhaust gases from the charging of coal and the pushing of coke.

The stack gases were collected by automatic isokinetic sampling according to US EPA method 23, and three samples were collected for each plant. The sampling train was composed of a heated probe liner, filter box equipped with a glass fiber filter and a water-cooled XAD-2 adsorbent trap. The glass fiber filter was used to collect particle-bound pollutants, and XAD-2 adsorbent resin was used for trapping the vapor-phase contaminants. Five surrogate target compounds (Wellington Laboratories, Guelph, Canada) were added into the XAD-2 resin in the adsorbent sampling cartridge before sampling. All samples were tightly wrapped in aluminum foil to avoid contamination and loss. After the end of sampling trip, the samples were immediately transferred to refrigerator where they were stored until analysis.

\subsection{Chemical analysis}

Twelve dl-PCBs and seventeen homologues of 2378-substituted PCDD/Fs were analyzed following the methods of US EPA method $1668 \mathrm{~A}$ and 23 modifications. The samples were spiked with the certain amounts of a ${ }^{13} \mathrm{C}_{12}$-PCBs mixture and ${ }^{13} \mathrm{C}_{12}$-PCDD/Fs inter- nal standard (Wellington Laboratories, Guelph, Canada), and carried out by Soxhlet extraction with $250 \mathrm{~mL}$ toluene for about $24 \mathrm{~h}$. Then, the extract was concentrated, and subjected to a series of cleanup by adsorption chromatography, including sulfuric acidtreated silica columns and multilayer silica gel columns. PCDD/Fs and dl-PCBs were fractionated by basic alumina columns. Prior to injection, ${ }^{13} \mathrm{C}_{12}$-labeled PCBs and ${ }^{13} \mathrm{C}_{12}$-labeled PCDD/Fs injection solutions (Wellington Laboratories, Guelph, Canada) were added into the corresponding fractions for calculation of recovery.

The analysis of dl-PCBs and PCDD/Fs was performed by an Agilent 6890 gas chromatograph coupled with Waters Autospec Ultima high-resolution mass spectrometry. Chromatographic separation was achieved with a DB-5 ms fused-silica column $(60 \mathrm{~m} \times$ $0.25 \mathrm{~mm}$ i.d. $\times 0.25 \mu \mathrm{m}$ ). The mass spectrometry was tuned and operated over 10000 resolution with $38 \mathrm{eV}$ EI energy. The data were acquired in the selected ion monitoring (SIM) mode.

\subsection{Quality assurance and quality control}

The sampling recoveries of the five surrogate standards for the three plants ranged from $70 \%$ to $107 \%$, excepted for ${ }^{13} C_{12}-1234789$ HpCDF for CP1 which was $62.6 \%$. The analytical recoveries are $40-$ $110 \%$ for nine ${ }^{13} \mathrm{C}_{12}$-labeled PCDD/Fs internal standards, and 70$120 \%$ for ${ }^{13} \mathrm{C}_{12}$-labeled dl-PCBs standards, respectively. These values met the requirements. Traveling blank was carried out to confirm that the samples were free from contamination during the trip period. The laboratory method blanks were also run for every batch of samples, and no interferences were observed.

\section{Results and discussion}

The concentrations of individual dl-PCB and PCDD/F congeners in dry standard conditions were shown in Table 2. For congeners with concentrations below LOD, a value of 0 was assigned for the calculation of total TEQ.

The WHO-TEQs of dl-PCBs were 87.7, 3.2, and $0.4 \mathrm{pg} \mathrm{Nm}^{-3}$ for $\mathrm{CP} 1, \mathrm{CP} 2$, and $\mathrm{CP} 3$, respectively. With regard to $\mathrm{PCDD} / \mathrm{Fs}$, the WHO-TEQs were $1697.7,55.2$, and $1.2 \mathrm{pg} \mathrm{Nm}^{-3}$ for CP1, CP2 and $\mathrm{CP} 3$, respectively. From these values, it could be seen that large variance of emission concentrations existed among three coke plants, and the concentration of dioxins from CP1 was far higher than CP2 and CP3. The technique and the end-of-pipe treatment were proved to be critically important factors for the formation and release of dioxins from thermally related processes in many studies (Tuppurainen et al., 1998; McKay, 2002). Thus, the coking technique and end-of-pipe control might be important factors influencing dioxins released from the coke plants. Higher emission concentration of $\mathrm{CP} 1$, as compared to $\mathrm{CP} 2$ and $\mathrm{CP} 3$, is possibly attributable to inadequate pollution control devices. For CP2 and $\mathrm{CP} 3$, the gases emitted from charging of the coal and pushing of the coke were treated by two separated dust arrestors. However, for $\mathrm{CP} 1$, the released gases from charging of the coal and the push-

Table 1

Basic information of the three coke plants.

\begin{tabular}{|c|c|c|c|}
\hline Denotation & $\mathrm{CP} 1$ & $\mathrm{CP} 2$ & CP3 \\
\hline Annual capacity (thousand tonne) & 200 & 512 & 1770 \\
\hline Technique of coal charging & Stamp charging & Top charging & Top charging \\
\hline Height of ovens (m) & 4.3 & 6 & 6 \\
\hline Coke quenching method & Water & Water & Nitrogen gas \\
\hline Air pollution control device (APCD) & Bag filters & Bag filters & Bag filters \\
\hline Content of oxygen in stack gas & 18 & 17 & 16 \\
\hline Total average flow rate $\left(\mathrm{Nm}^{3} \mathrm{~h}^{-1}\right)$ & 19103 & 79500 & 606390 \\
\hline Average temperature of stack gas $\left({ }^{\circ} \mathrm{C}\right)$ & 120 & 123 & 117 \\
\hline The operating time per year $(\mathrm{h})$ & 8760 & 8760 & 8760 \\
\hline
\end{tabular}


Table 2

Average levels of dl-PCBs and PCDD/Fs in stack gases from the three coke plants $\left(p g \mathrm{Nm}^{-3}\right)$.

\begin{tabular}{|c|c|c|c|}
\hline Pollutants & $\mathrm{CP} 1(n=3)$ & $\mathrm{CP} 2(n=3)$ & $\mathrm{CP} 3(n=3)$ \\
\hline CB-105 & 3475.2 & 586.7 & 181.7 \\
\hline CB-114 & 487.8 & 72.5 & 17.5 \\
\hline CB-118 & 7027.4 & 3211.5 & 1220.5 \\
\hline CB-123 & 987.4 & 600.3 & 242.9 \\
\hline CB-156 & 1380.4 & 260.7 & 121.1 \\
\hline CB-157 & 397.1 & 26.4 & 9.8 \\
\hline CB-167 & 444.2 & 111.4 & 46.0 \\
\hline CB-189 & 315.3 & 26.4 & 12.2 \\
\hline CB-77 & 1122.5 & 191.0 & 30.6 \\
\hline CB-81 & 382.3 & 145.6 & 39.1 \\
\hline CB-126 & 830.9 & 24.6 & 1.6 \\
\hline CB-169 & 211.5 & 3.3 & 0.6 \\
\hline$\sum W H O-T E Q(d l-P C B)$ & 87.7 & 3.2 & 0.4 \\
\hline 2378-TCDD & 164.0 & 7.5 & $<2.3$ \\
\hline 12378-PeCDD & 406.0 & 15.7 & $<3.5$ \\
\hline 123478-HxCDD & 208.7 & 10.2 & $<2.5$ \\
\hline 123678-HxCDD & 420.0 & 17.0 & $<2.7$ \\
\hline 123789-HxCDD & 211.4 & 11.4 & $<2.7$ \\
\hline 1234678-HpCDD & 1342.4 & 182.2 & 49.3 \\
\hline OCDD & 2338.2 & 287.0 & 97.8 \\
\hline 2378-TCDF & 1309.3 & 75.8 & 2.8 \\
\hline 12378-PeCDF & 647.3 & 7.0 & $<3.4$ \\
\hline 23478-PeCDF & 1332.6 & 15.7 & $<3.2$ \\
\hline 123478-HxCDF & 601.8 & 20.6 & $<1.9$ \\
\hline 123678-HxCDF & 580.7 & 23.7 & $<2.0$ \\
\hline 123789-HxCDF & 80.9 & 3.5 & $<1.9$ \\
\hline 234678-HxCDF & 582.6 & 34.1 & $<2.1$ \\
\hline 1234678-HpCDF & 1572.3 & 211.7 & 38.8 \\
\hline 1234789-HpCDF & 56.8 & 15.7 & $<3.9$ \\
\hline OCDF & 199.9 & 266.1 & 85.1 \\
\hline$\sum W H O-T E Q(P C D D / F s)$ & 1697.7 & 55.2 & 1.2 \\
\hline \multicolumn{4}{|l|}{$\sum$ WHO-TEQ } \\
\hline (PCDD/Fs and dl-PCBs) & 1785.4 & 58.3 & 1.6 \\
\hline
\end{tabular}

ing of coke were treated by only one dust arrestor. The reduced dust arrestor might decrease the ability of capturing dioxins by bag filters and lead to higher emission concentration to atmosphere. Furthermore, rather low emission concentration was detected for $\mathrm{CP}$, which is possibly related to the special coking process of $\mathrm{CP} 3$. For $\mathrm{CP} 3$, the gas emitted from charging of the coal was conducted into the adjacent combustion chambers, which might result in very low emission level of the dioxins. It was reported that the composition of raw materials in thermally related processes had significant influence on dioxins formations and emissions (Tuppurainen et al., 1998; Hatanaka et al., 2000; Wikström and Marklund, 2001; Wikstörm et al., 2003; Wang et al, 2003; Zheng et al., 2004). Therefore, the contents and forms of some elements in coal used for coke production, such as chlorine, copper, and sulfur, are supposed to also affect dioxin emissions. Additionally, the emission levels were also thought to be correlated with the different operation units. The study on effects of these factors on dioxins emission will be focused in our forthcoming contribution.

The concentrations of dl-PCBs from the investigated coke plants ranged from 0.4 to $87.7 \mathrm{pg}$ WHO-TEQ $\mathrm{Nm}^{-3}$. These values were very low compared with that of incinerators using electrostatic precipitator as APCD (Pernin et al., 1998; Dyke et al., 2003), but comparable with the dl-PCBs emission from iron ore sintering plants in the UK with the range of $42-111$ pg WHO-TEQ Nm ${ }^{-3}$ (Aries et al, 2006). Strong resemblance of dl-PCBs patterns between the iron ore sintering and the coking suggests that the pathways of dl-PCBs formation might be similar for the two categories of sources.

CB-118 was the most abundant congener among the dl-PCBs for many thermal related sources, environmental matrices and biological samples (Kim et al., 2004; Abad et al., 2006; Aries et al., 2006;
Zhao et al., 2006; Cok et al., 2007; Srogi, 2008). In this study, the concentration of $\mathrm{CB}-118$ was also the highest one, followed by CB-105, CB-123, CB-156 and CB-77. These five congeners together took up more than $70 \%$ in total dl-PCB concentration. Additionally, the abundance ratios of $\mathrm{CB}-126$ with the high toxicity compared with other dl-PCB congeners, were noted to be less than $5 \%$ in total dl-PCBs concentrations for all the three coke plants. However, due to its high WHO-TEF value of 0.1 , the contributions of CB-126 to total dl-PCB WHO-TEQ were greater than $95 \%, 75 \%$, and $60 \%$ for CP1, $\mathrm{CP} 2$, and $\mathrm{CP} 3$, respectively.

Bremmer et al. (1994) detected PCDD/Fs released from exit gas of a coke plant (quenching tower) with the concentration of $0.15 \mathrm{ng}$ I-TEQ $\mathrm{Nm}^{-3}$. In this study, the PCDD/Fs concentration of CP1 was about one order of magnitude higher than $0.15 \mathrm{ng}$ ITEQ Nm${ }^{-3}$, but the concentration from CP2 and CP3 was lower than the value reported by Bremmer et al. (1994).

Many studies (Fiedler et al., 2000; Buekens et al., 2001; Everaert and Baeyens, 2002; Chang et al., 2006) evaluated the common patterns of $\mathrm{PCDD} / \mathrm{Fs}$ in stack gas samples from thermal related sources, and concluded that the major contributors to the total concentrations of seventeen 2378-substituted congeners were OCDD, HpCDD, HpCDF, and OCDF. In this study, it was found that higher chlorinated PCDD/Fs, including 1234678-HpCDD, OCDD, $1234678-\mathrm{HpCDF}$ and OCDF, were also the dominant congeners in total concentrations of 2378-substituted PCDD/Fs, in spite of the distinct differences among the emission patterns of three coke plants. These results indicated that the stack emission pattern of coke plants presented the common emission characteristics of thermal related sources, and the formation mechanism of PCDD/ Fs in the coke production was similar with other thermal sources.

\section{Conclusions}

Based on the investigation, the annual emissions of the investigated plants were roughly estimated. The annual dioxins emission to air for CP1, CP2, and CP3 were estimated to be 15,2 , and $2 \mathrm{mg}$ WHO-TEQ for dl-PCBs, and 284, 38, $6 \mathrm{mg}$ WHO-TEQ for PCDD/Fs, respectively.

There were the hundreds of coke plants in China, the scales and facilities for coke production varied a lot with different coke plants. From this study, it could be seen that large variance of emission levels existed among different coke plants. Because of high data diversity, it was unfeasible to derive the emission factor and the total dioxins release from the whole coking industry based on the data of the three investigated coke plants. Further investigation on the emission of dioxins from coking industry is still in process.

\section{Acknowledgements}

This study was supported by Chinese Academy of Sciences (Grant No. KZCX2-YW-420), National 973 program (No. 2009CB421606) and National Natural Science Foundation of China (Nos. 20677070 and 20621703).

\section{References}

Abad, E., Martínez, K., Caixach, J., Rivera, J., 2006. Polychlorinated dibenzo-p-dioxins, dibenzofurans and "dioxin-like" PCBs in flue gas emissions from municipal waste management plants. Chemosphere 63, 570-580.

Aries, E., Anderson, D.R., Fisher, R., Fray, T.A.T., Hemfrey, D., 2006. PCDD/F and "Dioxin-like" PCB emissions from iron ore sintering plants in the UK Chemosphere 65, 1470-1480.

Bremmer, H.J., Troost, L.M., de Kuipers, G., Koning, J., Sein, A.A., 1994. Emissions of Dioxins in the Netherlands, Report No. 770501018. RIVM, Bilthoven, Netherlands.

Buekens, A., Stieglitz, L., Hell, K., Huang, H., Segers, P., 2001. Dioxins from thermal and metallurgical processes: recent studies for the iron and steel industry. Chemosphere 42, 729-735. 
Chang, M.B., Huang, H.C., Tsai, S.S., Chi, T.K., Chang, G.P., 2006. Evaluation of the emission characteristics of PCDD/Fs from electric arc furnaces. Chemosphere 62 1761-1773.

Çok, I.., Donmez, M.K., Satıroğlu, M.H., Aydınuraz, B., Henkelmann, B., Kotalik, J., Schramm, K.W., 2007. Concentration of polychlorinated dibenzo-p-dioxins, polychlorinated dibenzofurans and dioxin-like PCBs in human adipose tissue from Turkish men. Chemosphere 66, 1955-1961.

Dyke, P.H., Foan, C., Fiedler, H., 2003. PCB and PAH releases from power stations and waste incineration processes in the UK. Chemosphere 50, 469-480.

Everaert, K., Baeyens, J., 2002. The formation and emission of dioxins in large scale thermal processes. Chemosphere 46, 439-448.

Fiedler, H., Lau, C., Eduljee, G., 2000. Statistical analysis of patterns of PCDDs and PCDFs in stack emission samples and identification of a marker congener. Waste Manage. Res. 18, 283-292.

Hatanaka, T., Imagawa, T., Takeuchi, M., 2000. Formation of PCDD/Fs in artificia solid waste incineration in a laboratory-scale fluidized-bed reactor: influence of contents and forms of chlorine sources in high-temperature combustion. Environ. Sci. Technol. 34, 3920-3924.

Kim, K.S., Hirai, Y, Kato, M., Urano, K., Masunaga, S., 2004. Detailed PCB congene patterns in incinerator flue gas and commercial PCB formulations (Kanechlor). Chemosphere 55, 539-553.

McKay, G., 2002. Dioxin characterisation, formation and minimisation during municipal solid waste (MSW) incineration: review. Chem. Eng. J. 86, 343-368.

Pernin, H., Menard, T., Ferrieres, C., 1998. Coplanar PCB and dioxin emissions of 2 MSWI. Organohal. Compd. 36, 253-255.
Srogi, K., 2008. Levels and congener distributions of PCDDs, PCDFs and dioxin-like PCBs in environmental and human samples: a review. Environ. Chem. Lett. 6, 128.

Tuppurainen, K., Halonen, I., Ruokojärvi, P., Tarhanen, J., Ruuskanen, J., 1998. Formation of PCDDs and PCDFs in municipal waste incineration and its inhibition mechanisms: a review. Chemosphere 36, 1493-1511.

UNEP Chemicals, 2005. Standardized toolkit for identification and quantification of dioxin and furan releases. UNEP Chemicals, Geneva.

Wang, L.C., Lee, W.J., Lee, W.S., Chang-Chien, G.P., Tsai, P.J., 2003. Effect of chlorine content in feeding wastes of incineration on the emission of polychlorinated dibenzo-p-dioxins/dibenzofurans. Sci. Total Environ. 302, 185-198.

Wikström, E. Marklund, S., 2001. The influence of level and chlorine source on the formation of mono- to octa-chlorinated dibenzo-p-dioxins, dibenzofurans and coplanar polychlorinated biphenyls during combustion of an artificial municipal waste. Chemosphere 43, 227-234

Wikstörm, E., Ryan, S., Touati, A., Telfer, A., Tabor, D., Gullett, B., 2003. Importance of chlorine speciation on de Novo formation of polychlorinated dibenzo- $p$-dioxins and polychlorinated dibenzofurans. Environ. Sci. Technol. 37, 1108-1113.

Zhao, X., Zheng, M., Zhang, B., Zhang, Q., Liu, W., 2006. Evidence for the transfer of polychlorinated biphenyls, polychlorinated dibenzo-p-dioxins, and polychlorinated dibenzofurans from soil into biota. Sci. Total Environ. 368, 744-752.

Zheng, M., Liu, P., Piao, M., Liu, W., Xu, X., 2004. Formation of PCDD/Fs from heating polyethylene with metal chlorides in the presence of air. Sci. Total Environ. 328, 115-118. 